Int. J. Odontostomat., 4(1):47-52, 2010.

\title{
Reflections about Adhesive Systems
}

\author{
Reflexiones acerca de los Sistemas Adhesivos
}

\begin{abstract}
Marciano de Freitas Borges*; Pâmela Gutheil Diesel*; Fernanda Gomez Corrêa*; Eledana Bernardi*; Anelise Fernandes Montagner*; Jovito Adiel Skupien ${ }^{* *}$ \& Alexandre Henrique Susin ${ }^{* * *}$
\end{abstract} DE FREITAS B. M.; DIESEL, G. P.; CORREAA, G. F.; BERNARDI, E.; FERNANDES M. A.; SKUPIEN, J. A. \& SUSIN, A. H.
Reflections about adhesive systems. Int. J. Odontostomat., 4(1):47-52, 2010.

\begin{abstract}
The adhesive systems are responsible for an efficient union between teeth and resin, resulting in a longevity restoration. They are organic molecules di or multifunctional that contain reactive groups that interact with dentin and with the resin monomer of composite resin. The adhesive systems are characterized by wet adhesion, which is a result of presence of hidrophylics radicals in their compositions, to promote a better bond and the best properties of the adhesion. Adhesive systems may use two different strategies to interact with the dental structure: total-etching and self-etching technique. The total-etching systems require a conditioning, a rinsing and a priming step in order to allow involvement of collagen fibers by the resin monomers and the formation of the so-called 'hybrid layer'. The total-etching promotes the cleaning of dentin, also promotes superficial demineralization and delivers collagen fibrils to participate of an interface union mechanism teeth/ adhesive system/restorative material. Self-etching adhesive systems are characterized by demineralization and infiltration of resin monomers simultaneously. This technique is attractive because reduced sensitivity associated with retaining the smear layer and smear plugs, thereby, minimize the possibility of inadvertent contamination of the bonding surface with dentinal surface through dentinal fluid transudate.
\end{abstract}

KEY WORDS: adhesives systems, self-etching adhesives, total-etching adhesives.

\section{INTRODUCTION}

Since Buonocore (1955) introduced the acidetching technique which renders a more receptive for adhesion tooth surface, major developments, which had improved dentistry, have been taking place. This is due to the fact that adhesion is required to oppose and withstand contraction forces during polymerization of composite resin and to promote better retention and marginal integrity during functioning of the restored teeth (Davidson et al., 1994). Suitable monomers wet and interpenetrate the collagen, widen the fibrils network and form a resin-impregnated so-called hybrid layer that offers a mechanical coupling zone between the two substrates after the polymerization of resin (Nakabayashi et al., 1982; Pashley et al., 1993). These substrates are enamel and dentine that have different chemical composition, so they have different mechanical modulus in front of the adhesive systems and composite resin.
It is widely known that enamel is composed by $96 \%$ of inorganic material (calcium and phosphate) and $4 \%$ of organic material (amorphous substances), a proper characteristic. The enamel is composed by hydroxyapatite crystals highly oriented, forming prisms and involved by interprismatic enamel. The dentine is composed by $45 \%$ of inorganic material, $33 \%$ of amorphous organic substance and $22 \%$ of water and it has viscoelastic properties. Intertubular dentin, peritubular dentin and dentin tubules are observed microscopically (Van Meerbeek et al., 1993a). Dentin has more organic contents than enamel resulting in different ways of adhesion.

They are divided into two major simplified approaches to produce adequate hybridization and dentin bonds with the development of adhesives (Van Meerbeek et al., 1998). The first approach is the total-

\footnotetext{
* Graduate in Dentistry, Federal University of Santa Maria, Santa Maria, RS, Brazil.

** Post-graduate in Dentistry, Federal University of Santa Maria, Santa Maria, RS, Brazil.

${ }^{* * *}$ Department of Restorative Dentistry, Federal University of Santa Maria, Santa Maria, RS, Brazil; Professor.
} 
etching or TEAS (total-etching adhesive systems). This is a conventional adhesive system that uses an acid conditioner in a previous step (Gwinnett, 1992; Kanca, 1991, 1992a, 1992b). Total-etching adhesive has been shown to be partially effective because the complete replacement of rinsing water by adhesive monomers is unattainable within the short clinical time allowed for this step and always results in hybrid layers that contain voids (Van Meerbeek et al., 1993b; Wang \& Spencer, 2003). Such voids originated from spaces collagen fibrils that were not involved by the infiltrating resin, and are usually located at the bottom of hybrid layer, just above the mineralized dentin (Carvalho et al., 2005).

The second group is the self-etching, or SEAS (self-etching adhesive systems) that is applied in one or two steps. The self-etching removes minerals from the dentin surface while simultaneously replace them with the resin monomers. This process leaves no voids, theoretically, and consequently no nanoleakage would be expected at the interface (Carvalho et al.). Major disadvantages, however, are that systems use separate treatment for enamel and dentin, requiring several critical procedures of application. In studies of evaluation of the hybrid layer for self-etching and totaletching bond systems, the hybrid layer had a substantially higher modulus for the self-etching system and this may offer a possible explanation for the higher bond strengths even found (Oliveira et al., 2003).

The hybrid layer promotes better results of bond strength to the composite resin restoration, protects the restorative interface of microleakage and the tooth of the post-operative sensitivity because the interdiffusion of hydrophilic monomers into the demineralized area involves the collagen fibrils, providing a micro mechanical mechanism of retention.

Development. The adhesive systems are responsible for an efficient union between teeth and resin, resulting in a longevity restoration. They are organic molecules di- or multifunctional that contain reactive groups that interact with dentin and with the resin monomer of composite resin.

The adhesive systems are characterized by wet adhesion, which is a result of presence of hidrophylics radicals in their compositions, to promote a better bond and the best properties of the adhesion.

Adhesive systems may use two different strategies to interact with the dental structure: totaletching and self-etching technique.
Total Etching Strategy. The total-etching systems require a conditioning, a rinsing and a priming step in order to allow involvement of collagen fibers by the resin monomers and the formation of the so-called 'hybrid layer' (Carvalho et al.). Demineralization of intertubular dentin and maintenance of interfibrillar porosities are required for adequate monomer penetration into the conditioned dentin. The total-etching promotes the cleaning of dentin, also promotes superficial demineralization and delivers collagen fibrils to participate of an interface union mechanism teeth/ adhesive system/restorative material. Total-etching systems require relatively high concentrations of phosphoric acids (32-37\%) applied to dentin in a separate step. After etching, water rinse removes the acid and dissolves mineral and leaves the acid-insoluble collagen fibers suspended in water. This collagen network is highly hydrophilic and particularly sensitive to dehydration and shrinkage (Pashley et al.). The next step in the bonding process is to embed these fibrils with hydrophilic monomers. One approach is to use an aqueous solution of hydrophlic monomers such as HEMA in an intermediate step called priming (Nakabayashi \& Pashley, 1998). When gently dried with air, the HEMA-water-collagen mixture will slowly dehydrate but will remain fully expanded to allow the subsequent incorporation of the adhesive resin monomers (Pashley et al.). This method of use is the three-step total-etching adhesive systems.

Another kind of total-etching is "one-bottle" adhesives, which contain a mixture of organic solvents and resins (HEMA, BISGMA, TEGMA, UDMA) to impregnate the dentin tubules and collagen fibrils. In this method, acetone or alcohol, which quickly displace water in the collagen network, are the most used organic solvents because the driving force for water removal is better than with the HEMA-water primers. Therefore, these solutions accomplish a dynamic dehydration, because the rigidification of collagen fibers and the incorporation of the bonding resin occur simultaneously. However, recent research indicates that one-bottle adhesives increase the shrinkage of wetdecalcified dentin, thereby reducing infiltration of resin monomers. The advantage of these systems is the elimination of priming as a separate step, simplification of the procedure, and saving clinical time (Tay \& Pashley, 2001).

Whether a separate priming step is used, when adhesive resins penetrate into demineralized dentin and polymerize around the collagen fibrils forming the hybrid layer and dentinal tubules (Nakabayashi et al., 
1982). When dentin hybridization occurs at the peritubular dentin it is dissolved and resin TAGs are formed. This process is referred to as the hybridization of the resin tag (Nakabayashi \& Pashley). The intimate hybridization of both, the intertubular and peritubular dentin contributes to the waterproofing and bonding of resin-based materials to dentin (Tay \& Pashley).

Mostly current total-etching adhesives perform well in bond strength tests, at least when tested shortly after application and under controlled in vivo conditions (Inoue et al., 2001). However, the oral cavity is very dynamic because of enzymes of spittle, temperature changes, chewing, and chemical attacks by acids. So it forms a rather severe challenge for tooth-composite bonds to survive for a reasonably long time. Clinically, marginal degradation of composite restorations remains problematic and forms the greatest reason that reduces the lifetime of adhesive restorations (Van Meerbeeck et al., 1998).

A factor that is known to degrading toothcomposite bonds is exposure to water (Gwinnet \& Yu, 1995; Sano et al., 1995; Armstrong et al., 2001). Among different forms of marginal leakage, nanoleakage or the access of oral fluids through nanometer-size channels along collagen fibrils within the hybrid layer is considered very detrimental to bond integrity (Sano et al.; Hashimoto et al., 2000, 2002). As part of a totaletching procedure, the use of phosphoric acid almost impoverished completely the collagen of hydroxiapatite (Van Meerbeek et al., 1998). Consequently, adequate infiltration into, wetting of, and molecular interaction with hydroxyapatite depleted collagen by resin monomers is challenging, that may result in hybridization, leaving collagen unprotected and vulnerable to hydrolitic degeneration. Other degradation promoting factors are residual solvent of adhesive or insufficient removing of water from surface. Resin itself usually degrades over time and becomes more permeable, causing disintegration of resin/bond (Santerre et al., 2001).

Self Etching Strategy. Self-etching adhesive systems are characterized by demineralization and infiltration of resin monomers simultaneously. This technique is attractive because reduced sensitivity associated with retaining the smear layer and smear plugs, thereby, minimize the possibility of inadvertent contamination of the bonding surface with dentinal surface through dentinal fluid transudate (Tay et al., 2002a, 2002b, 2002c).

The development of self-etching systems avoided the occurrence of several disadvantages from total-etching systems. The hybridized complex of selfetching systems is comprised of a surface zone of hybridized smear layer and a subsurface zone of hybridized intertubular dentinal (Hayakawa et al., 1998; Bouillaguet, 2004). To achieve this goal, the self-etching primer should penetrate beyond the smear layer into intact mineralized dentin.

There are some advantages using self-etching primers on dentin. One advantage is that the thick smear layers may interfere in the diffusion of selfetching primers into the underlying intact dentin. This may be due to the physical presence of thick smear layers as a diffusion barrier or their ability to buffer acid monomers. Thick smear layers might affect the ability of self-etching systems to penetrate through intact mineralized dentin.

Contemporary self-etching systems have been developed by increasing the concentration of acidic resin monomers and combining them with HEMA (Eick et al., 1997). Then an increased interest on the study of interaction between these systems and smear layer thicknesses occurred. Another advantage is that separation of the hybridized smear layer from the true hybrid layer may occur because the underlying dentin is demineralized and hybridized. Also, true hybrid layers probably do not contain enough resinous material to integrate TAGs to the evolving hybrid layer, setting up the potential of leakage of fluids and microbial products into the pulp (Miyasak \& Nakabayashi, 1999).

A great variety of self-etching systems are presented in the market. They differ in number of the bottles, steps, acidity of the primer solution and resinous monomers. It might be speculated that selfetching systems with higher $\mathrm{pH}$ are less effective in solubilizing thick smear layers and demineralizing solid dentin surface for hybridization. The acid monomers are initially acid enough to completely dissolve the dentin crystals apatites, creating interfibrilar spaces that are wide enough to place monomers and solvent of the adhesive, however with the reaction, the buffered acid monomers gradually loose their ability to further etch dentin. So, thinner interfibrillar spaces may further down. These spaces probably contain products formed by dissolving calcium and phosphate ions liberated by the reaction. The intermixing of hydrophilic and hydrophobic monomers in one-step self-etching adhesive probably aggravates such a phenomenon (Carvalho et al.; Nakabayashi \& Pashley). 
It seems that depth of penetration of the selfetching adhesives into subsurface dentin varies according to the acidity of the self-etching system (Tay \& Pashley). Thin authentic hybrid layers are formed with a mild self-etching adhesive - approximately 0.5 $\mathrm{mm}$ thick -, whereas a moderate and an aggressive self-etching system usually forms thicker hybrid layers, in the range of $1.2-2.2$ and $2.5-5.0 \mathrm{~mm}$, respectively action than adhesives with lower $\mathrm{pH}$. In fact, previous literature reports have demonstrated that there is no correlation between bond strengths and hybrid layer thickness (Reis et al., 2005), and thus it seems that the ability to create thick hybrid layers cannot be considered as an additional advantage for improved retention. Another important aspect is the amount of solvents included in the self-etching priming solution. Water is present in all the self-etching systems employed because it is an essential component to enable ionization of the acidic monomers and demineralization of dental hard tissues. It is likely that the hybridized smear layer has as much affinity with water as does the authentic hybrid layer. The lack of correlation between the bond strengths of self-etching systems and the smear layer thickness can be considered an advantage, since it is clear from the literature findings that the thickness of the smear layer may vary according to the rotary instrument selected (Tani \& Finger, 2002).

The degradation of resin-dentin bonds was firstly attributed to hydrolysis of collagen fibrils at the base of the hybrid layer due to the incomplete penetration of resin monomers (Titley et al., 1995). In fact, discrepancies between the extent of demineralization and resin infiltration may not be the sole reason for bond strength decrease. Therefore, other factors should be considered. Hydrolytic degradation of polymers observed after water sorption and the permeability of the adhesive layer are likely the cause.

Morphological evidence that there is discrepancy between the depth of demineralization and the depth of resin infiltration have potential to occur in some mild self-etching adhesives. So, they are concluding that a zone of partially etched but uninfiltrated dentin was identified beneath the hybrid layers in the milder versions of both one-step and two-step self-etching adhesives (Carvalho et al.).

An uninfiltrating zone into the dentin that is observed in some self-etching adhesives is probably caused because of the reducing etching potential of the acid monomers near the base of hybrid layers, or the presence of acid but non-polymerizable hydrolytic adhesive components producing sites that contain nanoleakage (Sano et al.) that was originally adopted to depict areas within the hybrid layer that were not fully infiltrated by resin (Nakabayashi \& Pashley; Carvalho et al.). This concept was more recently extended to include other water-filled voids that occur within adhesive layers (Sano et al.; Tay \& Pashley; Ferrari \& Tay, 2003). Apart from the observation of some studies, nanoleakage within the hybrid and adhesive

Table I. Composition of the adhesive systems.

\begin{tabular}{|c|c|c|}
\hline Classification & Adhesive systems & Composition \\
\hline \multirow{5}{*}{$\begin{array}{l}\text { Total } \\
\text { Etch } \\
\text { Adhesive }\end{array}$} & Scotchbond MP Plus & Conditioner: $35 \%$ phosphoric acid $(\mathrm{pH} 0.02)$ \\
\hline & (conventional three & Primer:HEMA, PAA and water (pH 3.5) \\
\hline & $\begin{array}{l}\text { step) - 3M ESPE, St. } \\
\text { Paul, MN, USA }\end{array}$ & Adhesive: Bis-GMA and HEMA \\
\hline & $\begin{array}{l}\text { Prime \& Bond - } \\
\text { Dentsply/ DeTrey, } \\
\text { Konstanz, Germany }\end{array}$ & $\begin{array}{l}\text { Conditioner: } 34 \% \text { phosphoric acid } \\
\text { Adhesive: PENTA, urethane di methacrylate, T-resin, D-resin, butylated } \\
\text { hydroxitoluene, 4-ethyl dimethyl aminobenzoate, cetylamine } \\
\text { hydrofluoride, acetone, silica nanofiller }\end{array}$ \\
\hline & $\begin{array}{l}\text { Single Bond (one } \\
\text { bottle) } \\
-3 \text { M ESPE, St. Paul, } \\
\text { MN, USA }\end{array}$ & $\begin{array}{l}\text { Conditioner: } 35 \% \text { phosphoric acid }(\mathrm{pH} 0.02) \\
\text { Adhesive: Bis-GMA,HEMA, PAA, ethanol and water }\left(\mathrm{pH}^{\star}\right)\end{array}$ \\
\hline \multirow{3}{*}{$\begin{array}{l}\text { Self } \\
\text { Etch } \\
\text { Adhesive }\end{array}$} & $\begin{array}{l}\text { Clearfil SE Bond - } \\
\text { Kuraray Co. Ltd., }\end{array}$ & $\begin{array}{l}\text { SE-Primer: MDP, HEMA, CQ, N.N-diethanol p-toluidine, hydrophilic } \\
\text { dimethacrylate and water ( } \mathrm{pH} \text { 2) }\end{array}$ \\
\hline & Osaka, Japan & $\begin{array}{l}\text { SE-Bond: Bis-GMA,HEMA, hydrophobic dimethacrylate, CQ, N.N- } \\
\text { diethanol p-toluidine, silanated colloidal silica }\end{array}$ \\
\hline & $\begin{array}{l}\text { Etch \& Prime - } \\
\text { Degussa AG, Hanau, } \\
\text { Germany }\end{array}$ & Universal: HEMA, ethanol and water \\
\hline
\end{tabular}

\footnotetext{
*pH as repoted by the manufacture; HEMA = 2-hydroxyethil methacrylate; $\mathrm{PAA}=$ polyalkenolic acid copolymer; Bis-GMA= bisphenol glycidyl methacrylate PENTA = dipentaerythritol penta acrylate mono phosphate; $\mathrm{MDP}=10$-methacryloloxydecil-dihydrogen phosphate; $\mathrm{CQ}=$ dil-camphorquinone
} 
layers, the presence of a zone of porous mineralized dentin in Xeno III, ibond, Brush \& Bond, and the experimental self-etching adhesive suggest that the mineralized dentin adjacent to the hybrid layer created by some procedures became porous enough to take up water and silver nitrate. As such layer was seen with Clearfil SE Bond and Clearfil Protect Bond, and was absent in Adper Prompt, AdheSE, Tyrian/ One Step Plus, OptiSolo Plus Self-etching, its occurrence may be material dependent, and not exclusive for one-step self etching adhesives (Nakabayashi \& Pashley).
Treating the enamel and dentin with self conditioning monomer solutions instead of employing a conventional total-etching procedure is a simple method to prevent the collapse of collagen network (Watanabe et al., 1994). When self-etching primers are used, there is no need of etching, rinsing and drying so that the risk of over-etching and over-drying of the dentin is eliminated. Self-etching primers are extremely fast and simple to apply in clinical situations, and dramatically reduce the technique sensitivity of the bonding procedure.

DE FREITAS B. M.; DIESEL, G. P.; CORREAA, G. F.; BERNARDI, E.; FERNANDES M. A.; SKUPIEN, J. A. \& SUSIN, A. H. Reflexiones acerca de los sistemas adhesivos. Int. J. Odontostomat., 4(1):47-52, 2010.

RESUMEN: Los sistemas adhesivos son responsables de una unión eficaz entre los dientes y la resina, dando como resultado una restauración durable. Son moléculas orgánicas bi o multifuncionales que contienen grupos reactivos que interactúan con la dentina y con el monómero de resina de composite. Los sistemas adhesivos se caracterizan por la adhesión húmeda, que es el resultado de la presencia de radicales hidrofílicos en sus composiciones, para promover una mejor adherencia y las mejores propiedades de la adhesión. Los sistemas adhesivos pueden utilizar dos estrategias diferentes para interactuar con la estructura dental: Técnica de grabado total y auto-grabado. Los sistemas de grabado total requiere un acondicionamiento, un lavado y un paso de priming con el fin de permitir la participación de las fibras de colágeno por los monómeros de resina y la formación de la llamada capa híbrida. El grabado total promueve la limpieza de la dentina, también promueve la desmineralización superficial y condiciona a las fibrillas de colágeno para participar de un mecanismo de interfaz de unión diente/sistema adhesivo /material de restauración. Los sistemas adhesivos autograbantes se caracterizan por la desmineralización y la infiltración de los monómeros de resina de forma simultánea. Esta técnica es atractiva debido a la sensibilidad reducida asociada a conservar la capa de barro dentinario y tapones de barro dentinario, reduciendo al mínimo la posibilidad de contaminación accidental de la superficie de unión con la superficie de la dentina a través del líquido dentinario trasudado.

PALABRAS CLAVE: sistemas adhesivos, adhesivos autograbantes, adhesivos de grabado total.

\section{REFERENCES}

Armstrong, S. R.; Keller, J. C. \& Boyer, D. B. The influence of water storage and $\mathrm{C}$-factor on the dentin-resin composite microtensile bond strength and debond pathway utilizing a filled and unfilled adhesive resin. Dent. Mater., 17(3):268-76, 2001.

Bouillaguet, S. Biological risks of resin-based materials to the dentin-pulp complex. Crit. Rev. Oral Biol. Med., 15(1):47-60, 2004.

Bounocore, M. G. A simple method of increasing the adhesion of acrylic filling materials to enamel surfaces. J. Dent. Res., 34:849-53, 1955.

Carvalho, R. M.; Chersoni, S.; Frankenberger, R.; Pashley, D. H.; Prati, C. \& Tay F. R. A challenge to the conventional wisdow that simultaneously etching and resin infiltration always occur in self-etch adhesives. Biomaterials, 26:1035-42, 2005.

Davidson, C. L.; de Gee, A. J. \& Feilzer, A. The competition between the composite-dentin bond strength and the polymerization contraction stress. J. Dent. Res., 63:13969, 1994.

Eick, J. D.; Gwinnett, A. J.; Pashley, D. H. \& Robinson, S. J. Current concepts on adhesion to dentin. Crit. Rev. Oral Biol. Med., 8:306-35, 1997.

Ferrari, M. \& Tay, F. R. Technique sensitivity in bonding to vital acid-etched dentin. Oper. Dent., 28:3-8, 2003.

Gwinnett, A. J. Moist versus dry dentin: its effect on shear bond strength. Am. J. Dent., 5:127-9, 1992.

Gwinnett, A. J. \& Yu, S. Effect of long-term water storage on dentin bonding. Am. J. Dent., 8(2):109-11, 1995.

Hashimoto, M.; Ohno, H.; Endo, K.; Kaga, M.; Sano, H. \& Oguchi, $\mathrm{H}$. The effect of hybrid layer thickness on bond strength: demineralized dentin zone of the hybrid layer. Dent. Mater., 16(6):406-11, 2000. 
Hashimoto, M.; Ohno, H.; Kaga, M.; Sano, H.; Tay, F. R.; Oguchi, H.; Araki, Y. \& Kubota, M. Over-etching effects on micro-tensile bond strength and failure patterns for two dentin bonding systems. J. Dent., 30(2-3):99-105, 2002.

Hayakawa, T.; Kikutake, K. \& Nemoto, K. Influence selfetching primer treatment on the adhesive of resin composite to polished dentin and enamel. Dent. Mater., 14:99-105, 1998.

Inoue, S.; Vargas, M. A.; Abe, Y.; Yoshida, Y.; Lambrechts, P.; Vanherle, G.; Sano, H. \& Van Meerbeek, B. Microtensile bond strength of eleven contemporary adhesives to dentin. J. Adhes. Dent., 3(3):237-45, 2001.

Kanca, J. Effect of dentin drying on bond strength. J. Dent. Res., 70:1029, 1991.

Kanca, J. 3rd. Resin bonding to wet substrate I Bonding to dentin. Quintessence. Int., 23:39-41, 1992a.

Kanca J. Efect of resin primer solvents and surface wetness on resin composite bond streght to dentin. Am. J. Dent., 5:213-5, 1992b.

Miyasak, K. \& Nakabayashi, N. Combination of EDTA conditioner and Phenyl-P/HEMA self-etching primer for bonding to dentin. Dent. Mater., 15:153-7, 1999.

Nakabayashi, N. \& Pashley, D. H. Hybridization of dental hard tissues. Tokyo, Quintessence Publishing Co., 1998. pp.54-6.

Nakabayashi, N.; Kojima, K. \& Masuhara, E. The promotion adhesion by the infiltration of monomers into tooth substrates. J. Biomed. Mat. Res., 16:265-73, 1982.

Oliveira, S. A, Pugach, M. K.; Hilton, J. F.; Watanabe, L. G. \& Marshall S. J. The influence of the dentin smear layer on adhesion: a self-etching primer vs. a total-etch system. Dent Mater., 19(8):758-67, 2003.

Pashley, D. H.; Ciucchi, B.; Sano, H. \& Horner, J. A. Permeability of dentin to adhesive agents. Quintessence Int., 24(9):618-31, 1993.

Reis, A.; Grandi, V.; Carlotto, L.; Bortoli, G.; Patzlaff, R.; Accorinte, M. L. R. \& Loguercio, A. D. Effect of smear layer thickness and acidity of self-etching solutions on early and long-term bond strength to dentin. J. Dent., 33(7):549-59, 2005.

Sano, H.; Takatsu, T.; Ciucci, B.; Horner, J. A.; Matthews, W. G. \& Pashley, D. H. Nanoleakage: leakage within the hybrid layer. Oper. Dent., 20:18-25, 1995.

Santerre, J. P.; Shajii, L. \& Leung, B. W. Relation of dental composite formulations to their degradation and the release of hydrolyzed polymeric-resin-derived products. Crit. Rev. Oral Biol. Med., 12(2):136-51, 2001.

Tay, F. R.; Carvalho, R. M.; Sano, H. \& Pashley, D. H. Effect of smear layers on the bonding of a self-etching primer to dentin. J. Adhes. Dent., 2:99-116, 2002a.

Tay, F. R. \& Pashley, D. H. Aggressiveness of contemporary self-etching systems. I: Depth of penetration beyond dentin smear layers. Dent. Mater., 17:296-308, 2001.

Tay, F. R.; Pashley, D. H.; Suh, B. I.; Carvalho, R. M. \& Itthagarun, A. Single-step adhesives are permeable membranes. J. Dent. 30:371-82, 2002b.

Tay, F. R.; Pashley, D. H. \& Yoshyiama, M. Two modes of nanoleakage expression in single-step adhesives. J. Dent. Res. 81:472-6, 2002c.

Tani, C. \& Finger, W. J. Effect of smear layer thickness on bond strength mediated by three all-in-one self-etching priming adhesives. J. Adhes. Dent., 4:283-9, 2002.

Titley, K.; Chernecky, R.; Chen, A. \& Smith, D. The composition and ultrastructure of resin tags in etched dentine. Am. J. Dent., 8(5):224-30, 1995.

Van Meerbeek, B.; Willems, G.; Celis, J. P.; Roos, J. R.; Braem, M.; Lambrechts, P. \& Vanherle, G. Assessment by nano-indentation of the hardness and elasticity of the resin-dentin bonding area. J. Dent. Res., 72:1434-42, 1993b.

Van Meerbeek, B.; Mohrbacher, H.; Celis, J. P.; Roos, J. R.; Bram, M.; Lambrechts, P. \& Vanherle, G. Chemical characterization of the resin-dentin interface by microRaman spectroscopy. J. Dent. Res., 72(10):1423-8, 1993a.

Van Meerbeek, B.; Perdigão, J.; Lambrechts, P. \& Vanherle, G. The clinical performance of adhesives. J. Dent. Res., 73:1-20, 1998.

Watanabe, I.; Nakabayashi, N. \& Pashley, D. H. Bonding to ground dentin by a phenyl-P self-etching primer. J. Dent. Res., 73:1212-20, 1994.

Wang, Y. \& Spencer, P. Hybridization efficiency of the adhesive/dentin interface with wet bonding. J. Dent. Res., 82:141-5, 2003.

Correspondence to:

Alexandre Henrique Susin

Department of Restorative Dentistry

Federal University of Santa Maria

Santa Maria, RS

BRAZIL

Received: 17-11-2009

Email: ahsusin@brturbo.com.br
Accepted: 22-01-2010 